\title{
EDITORIAL
}

\section{The Problem of Fragmentation and the Need for Integrative Solutions}

\author{
Kurt C. Stange, $M D, P b D$, Editor \\ Ann Fam Med 2009;7:100-103. DOI: 10.1370/afm.971.
}

AN

\section{AN INTERACTIVE SERIES}

$\mathrm{n}$ the United States ${ }^{1,2}$ and around the world ${ }^{3}$ we face enormous healthcare problems of unsustainable cost

increases, poor quality, and inequalities. The low value of the US healthcare system and analogous difficulties in other countries have elicited calls for bold action. Strategic action, however, requires a deeper than surface understanding of the problem.

This is the first in a series of commentaries designed to help make sense of the problems and opportunities we face for understanding and improving health care and health. This series will address the following issues:

- The problem of fragmentation that underlies the more obvious health care crisis

- A generalist solution-to reducing fragmentation and fostering integration

- The nested hierarchy of health care-how health care can be organized to enable the higher levels that are unintentionally devalued by current approaches

- The paradoxical payoff of primary care-better whole-person and system outcomes despite apparently poorer quality disease-specific care

- Ways of knowing in health and health care-how understanding development in 4 complementary domains can inform a science and practice of integrated health care

- Cycles of renewal and adaption - that identify useful strategies for the current unstable position in the health care cycle

Your interaction with these ideas by reading and contributing comments at http://annfammed.org/cgi/ eletter-submit/7/2/100 can be a nidus for hope, even as cynics argue that transformative change is not possible. The nattering nabobs of negativity ${ }^{4}$ are thinking too narrowly. Real change is possible with a different view that allows integrated solutions to emerge.

\section{THE PROBLEM OF FRAGMENTATION}

A wealthy man I know went from doctor to doctor to try to find a reason for his fatigue. Each doctor looked in depth at the organ in which (s)he was an expert. Each did the latest tests. Each prescribed the latest drugs and devices. And the patient, the person, got worse. He was in charge of his healthcare; he bought the best of each commodity; but in the end his fatigue remained and he only felt more alone.

This man's experience was the opposite of healing. Healing requires relationships-relationships which lead to trust, hope, and a sense of being known. ${ }^{5}$ But our healthcare system doesn't deliver healing. It doesn't deliver relationships. Increasingly it delivers commodities that can be sold, bought, quantified, and incentivized. While the whole-whole people, whole systems, whole communities— gets worse. ${ }^{6}$ While governments, health care systems, and individuals spend more and more on healthcare, for less and less value.

Focused laboratory research is needed to understand the behavior of discrete treatments for discrete diseases, but improving health is fostered by a different science, one that considers the behavior of multiple interacting factors which advance the health of whole people within communities. It is the poor generalist health professional who considers only the disease and not the whole person. It is the poor policy maker that designs health care systems that deal only with discrete diseases and fails to create environments that support creative interaction between different parts of the system. ${ }^{6,7}$

Underlying the current healthcare failings is a critical underappreciated problem: fragmentationfocusing and acting on the parts without adequately appreciating their relation to the evolving whole. . $^{8-10}$ This unbalance, this brokenness, is at the root of the more obvious healthcare crises of unsustainable cost increases, poor quality, and inequality. Fragmentation is at the heart of the ineffectiveness of our increasingly frantic efforts to nurture improvement.

Knowledge advanced greatly in the modern era by making sense of complicated things by understanding their parts. The ensuing rise in specialization ${ }^{11}$ has led 
to breathtaking advances from isolating, partitioning, and manipulating the components of physical, biological, and human systems. More recently, new insights in biology, physics, human organization, and other fields have led to understanding complex systems as more than the sum of their parts. ${ }^{12-15}$ Because of our fragmented understanding of the natural world, systems, and human interactions, however, health care has not kept up with these advances. ${ }^{16-20}$ Specialized information has expanded without a similar expansion in our ability to integrate, prioritize, and personalize narrowly construed information. As a result, our ability to turn information into knowledge and knowledge into wisdom has diminished. ${ }^{21}$

\section{The Unintended Consequences of Well-Intentioned Actions}

The invisibility of this problem is important because fragmentation leads to well-intentioned actions that sometimes have the unintended consequence of making things worse. ${ }^{22}$ These unintended consequences include the following:

\section{Inefficiency}

A cacophony of narrowly-focused programs and services is an excellent strategy for expanding revenues for service and commodity providers. It is not a strategy for efficiently delivering health care. ${ }^{23}$ Efficient health care requires an ability to personalize and prioritize based on "an acquaintance with the particulars," 24 seen in the context of whole people, communities and systems. It is no coincidence that US healthcare is both the most fragmented and most costly in the world. ${ }^{25}$

\section{Ineffectiveness}

Likewise, it is no fluke that the technologically advanced but fragmented US healthcare system ranks 37 th in the performance of its healthcare system. ${ }^{26}$ Spending more on the parts has not improved the whole. Similar criticisms of fragmented disease-by-disease efforts by the World Health Organization have been raised on the 30th anniversary of the Alma Ata plan for "providing a comprehensive, universal, equitable and affordable healthcare service for all."27-29 Today the efforts of public health, healthcare systems, and philanthropists are directed at narrow programs with insufficient attention to the larger whole they are trying to affect. Because of the lack of an integrative way of making sense of the world, the need to control and understand narrowly and the short-term incentives to divide and profit replace the greater promise of whole-system approaches. Because of the fragmentary configuration of current scientific evidence, ${ }^{30}$ the narrowly defined "performance" that is being incentivized in pay-for-per- formance $^{31}$ schemes risks unintentionally disincentivizing optimal care of whole people and populations. ${ }^{32-34}$

\section{Inequality}

In a fragmented system, it is easy to ignore the poor. ${ }^{35}$ Doctors treat whoever comes through the door, often oblivious to the many barriers to entry. Manufacturers make their products based on economic niche more than public good. ${ }^{23}$ Hospitals and healthcare systems strive to attract "the right case mix" to maximize profits, or just to stay in business. A patchwork of safety nets is stretched to their limits, and many people fall between the nets. ${ }^{36-38}$ The human and economic costs of unjustness are staggering for individuals and communities deprived of health and its benefits for society. ${ }^{39-40}$ Further, the spiral of spending on healthcare risks worsening inequalities by siphoning resources from the social determinants of health that are even more important drivers of equitable population health. ${ }^{39}$

\section{Commoditization}

Treating healthcare (one word) as a commodity can unintentionally devalue health care (two words). Health care involves relationships. Disease management programs are bought and sold with a trumping emphasis on the disease and a secondary focus on the person experiencing the illnesses. ${ }^{41}$ Information technology systems support narrowly evidence-based care of individual diseases, rather than higher level integration of care for prevention, mental health, multimorbid conditions, and acute concerns. ${ }^{42-46}$ Knowledge generation is narrowly partitioned in disease-specific institutes and initiatives without sufficient balancing research that transcends these boundaries. Specialists, drug and device makers, hospitals and service agencies focus on delivering their well-reimbursed services without a way to consider their effect on the whole person or system, or the opportunity costs on the social determinants of health, such as education and employment. ${ }^{39}$ The promise of health care is reduced when it is treated as a commodity-when patients become customers, citizens become consumers, healers become providers, and costs for the public good of health care are shifted around like the proverbial hot potato.

\section{Commercialization}

The recent worldwide financial meltdown shows that the tremendous benefits of the market must be balanced by incentives toward the larger societal good. ${ }^{47}$ Although private provision of healthcare services sometimes motivates convenience and satisfaction among those able to access services, private financing of healthcare disastrously has left too many out while fostering harmful overuse of marginal services by oth- 
ers. ${ }^{48,49}$ Convenience and satisfaction are not the most important health care endpoints, and the pipe dream of a fully informed marketplace making the right healthcare decisions has been shown to be woefully unrealistic. ${ }^{50}$ The failed free market ideology of the US healthcare system is being willingly imported by other countries to the detriment of more systemic approaches.

\section{Deprofessionalization}

By focusing their role narrowly on a technical skill, procedure, or body part, healthcare professionals have completed one part of their contract with society. ${ }^{51,52}$ But in focusing narrowly on expertise without also attending to their responsibility to the whole person and to society, healthcare providers have accepted the rewards of a profession without accepting the full responsibility. In buying into (and being paid well for delivering) manufacturing-inspired productivity models of healthcare, we have lost our professionalism and sold our souls without even noticing the transaction. We have settled for being technicians rather than compassionate healers in covenant with our communities. We have forgotten that higher levels of healing are possible by balancing the biotechnical with the biographical. ${ }^{54}$

\section{Depersonalization}

Osler is quoted as saying "It is more important to know what sort of person has a disease than to know what sort of disease a person has." 54 The experience of healthcare in the United States, however, too often is one of not being known as a person. This experience affects the poor, who have difficulty getting access to basic medical care until their problems are emergencies. But it also is experienced by the rich and middle class, who receive as much (and often more) of the sometimes dangerous ${ }^{49}$ commodities of healthcare as they want but feel abandoned when they need help putting together the pieces of their illness-shattered lives into a meaningful whole. ${ }^{55}$

\section{Despair and Discord}

Patients appear to be more dissatisfied with healthcare in more fragmented systems. ${ }^{56}$ Indeed, the failure of repeated fragmented attempts to fix the problems can result in a kind of shared hopelessness. When we see only parts, disconnected from the whole, we lose our ability to find incremental actions that are connected to larger evolutionary improvement. The search for single sustainable solutions gets in the way of fostering development toward equitable, integrated, personalized, prioritized health care. Furthermore, the fragmentation of healthcare leads to a get-what-you-can mentality among all involved. Developing shared goals, such as those present and sometimes beset in the Brit- ish National Health Service, ${ }^{57-60}$ requires continuous attention, but discernment of how each person's health and health care affects the others can provide a platform for seeking a better way together.

\section{Understanding the Problem}

Understanding the fundamental problem of fragmentation in our disintegrating healthcare system is an important first step. Viewing health care as an evolving whole instead of only as fragmented parts can help us to feel hope where now there is cynicism. Personalization and relationship where now there is detachment and isolation. Professional and corporate shared responsibility where now there is narrow self-interest. High value health care where now there is waste and inequality. Maximizing the opportunities for health and healing, and abiding when healing and health are not possible.

In his inaugural address, President Obama decried "our collective failure to make hard decisions." An important first decision is to work to understand critical and actionable aspects of the problem. To improve health care and health, the hard and joyful choices necessary to reduce fragmentation await our thinking and acting differently.

In the next issue-the generalist solution.

To read or post commentaries in response to this article, see it online at http://www.annfammed.org/cgi/content/full/7/2/100.

Acknowledgments: I am grateful to Frank deGruy, Robert Ferrer, Ken Frisof, Robin Gotler, Larry Green, Ann Louise Kinmonth, William Miller, and Paul Thomas for helpful and challenging comments on earlier versions of this piece. The final decision to accept or refuse their sage advice was mine.

Funding support: Dr Stange is partially supported by a Clinical Research Professorship from the American Cancer Society.

\section{References}

1. Smedley BD, Stith AY, Nelson AR. Institute of Medicine. Unequal Treatment: Confronting Racial and Ethnic Disparities in Healthcare. Washington, DC: The National Academies Press; 2003.

2. Institute of Medicine. Committee on Quality of Helath Care in America. Crossing the Quality Chasm: A New Health System for the 21st Century. Washington, DC: National Academy Press; 2001.

3. World Health Organization. Primary Health Care-Now More Than Ever. The World Health Report 2008. http://www.who.int/whr/2008/en/.

4. Agnew ST. Address to the California Republican state convention, San Diego, California, In: Congressional Record, September 16, 1970;116:32017.

5. Scott JG, Cohen D, DiCicco-Bloom B, Miller WL, Stange KC, Crabtree BF. Understanding healing relationships in primary care. Ann Fam Med. 2008;6(4):315-322.

6. Thomas P. Integrating Primary Health Care: Leading, Managing, Facilitating. Oxford, UK: Radcliffe Publishing; 2006.

7. Fisher ES. Building a medical neighborhood for the medical home. N Engl J Med. 2008;359(12):1202-1205.

8. Ransom DC. Random notes: the patient is not a dirty window. Fam Syst Med. 1984;(Summer):230-233. 
9. Ransom DC. The evolution from an individual to a family approach In: Henaos S, Grose N, eds. In: Principles of Family Systems in Family Medicine. New York, NY: Brunner-Mazel; 1985:5-23.

10. Stange KC. The paradox of the parts and the whole in understanding and improving general practice. Int J Qual Health Care. 2002;14(4):267-268.

11. Foucault M. The Birth of the Clinic: An Archaeology of Medical Perception. New York, NY: Vintage Books; 1975.

12. Williams GP. Chaos Theory Tamed. Washington, DC: John Henry Press; 1997.

13. Wolfram S. A New Kind of Science. Champaign, IL: Wolfram Media; 2002.

14. Stacey RD. Complexity and Creativity in Organizations. 1st ed. San Francisco, CA: Berrett-Koehler Publishers; 1996.

15. Lenski RE, Barrick JE, Ofria C. Balancing robustness and evolvability. PLoS Biol. 2006;4(12):e428.

16. Plsek PE, Greenhalgh T. Complexity science: the challenge of complexity in health care. BMJ. 2001;323(7313):625-628.

17. Kernick D. Complexity and Healthcare Organization: A View From the Street. San Francisco, CA: Radcliffe Medical Press; 2004.

18. Sweeney K. Complexity in Primary Care. Oxon, UK: Radcliffe Publishing Ltd; 2006.

19. Engel GL. The need for a new medical model: a challenge for biomedicine. Science. 1977;196(4286):129-136.

20. Borrell-Carrio F, Suchman AL, Epstein RM. The biopsychosocial model 25 years later: principles, practice, and scientific inquiry. Ann Fam Med. 2004;2(6):576-582.

21. Elliot TS. The Rock. New York, NY: Faber \& Faber; 1934.

22. May RM. Science and society. Science. 2001;292(5519):1021.

23. Woolf SH, Johnson RE. The break-even point: when medical advances are less important than improving the fidelity with which they are delivered. Ann Fam Med. 2005;3(6):545-552.

24. McWhinney IR. An acquaintance with particulars.... Fam Med. 1989;21(4):296-298.

25. Starfield B. Is US health really the best in the world? JAMA. 2000;284(4):483-485.

26. World Health Organization. World Health Organization Assesses the World's Health Systems. The World Health Report. http://www.who. int/whr/2000/media_centre/press_release/en/index.html. Accessed Jan 15, 2009.

27. Gunn JM, Palmer VJ, Naccarella L, et al. The promise and pitfalls of generalism in achieving the Alma-Ata vision of health for all. Med J Aust. 2008;189(2):110-112.

28. McPake B, Mensah K. Task shifting in health care in resource-poor countries. Lancet. 2008;372(9642):870-871.

29. van Weel C, De Maeseneer J, Roberts R. Integration of personal and community health care. Lancet. 2008;372(9642):871-872.

30. Fortin M, Dionne J, Pinho G, Gignac J, Almirall J, Lapointe L. Randomized controlled trials: do they have external validity for patients with multiple comorbidities? Ann Fam Med. 2006;4(2):104-108.

31. Doran T, Fullwood C, Gravelle H, et al. Pay-for-performance programs in family practices in the United Kingdom. N Engl J Med. 2006;355(4):375-384.

32. Weyer SM, Bobiak S, Stange KC. Possible unintended consequences of a focus on performance: insights over time from the research association of practices network. Qual Manag Health Care. 2008;17(1):47-52.

33. Roland M. Pay-for-performance: too much of a good thing? A conversation with Martin Roland. Interview by Robert Galvin. Health Aff (Millwood). 2006;25(5):w412-w419.

34. Campbell SM, McDonald R, Lester $H$. The experience of pay for performance in english family practice: a qualitative study. Ann Fam Med. 2008;6(3):228-234.
35. Mercer SW, Watt GC. The inverse care law: clinical primary care encounters in deprived and affluent areas of Scotland. Ann Fam Med. 2007;5(6):503-510.

36. Devoe JE, Baez A, Angier H, Krois L, Edlund C, Carney PA. Insurance + access not equal to health care: typology of barriers to health care access for low-income families. Ann Fam Med. 2007;5(6):511-518.

37. DeVoe J. The unsustainable US health care system: a blueprint for change. Ann Fam Med. 2008;6(3):263-266.

38. Fiscella K, Franks P, Gold MR, Clancy CM. Inequality in quality: addressing socioeconomic, racial, and ethnic disparities in health care. JAMA. 2000;283(19):2579-2584.

39. World Health Organization. Commission on Social Determinants of Health - Final Report. 2008. http://www.who.int/social_determinants/ final_report/en/index.html. Accessed Jan 30, 2009.

40. Woolf SH. Society's choice: the tradeoff between efficacy and equity and the lives at stake. Am J Prev Med. 2004;27(1):49-56.

41. Geyman JP. Disease management: panacea, another false hope, or something in between? Ann Fam Med. 2007;5(3):257-260.

42. Fortin M, Bravo G, Hudon C, Vanasse A, Lapointe L. Prevalence of multimorbidity among adults seen in family practice. Ann Fam Med. 2005;3(3):223-228

43. Fortin M, Bravo G, Hudon C, Lapointe L, Dubois MF, Almirall ]. Psychological distress and multimorbidity in primary care. Ann Fam Med. 2006;4(5):417-422.

44. Fortin M, Soubhi $H$, Hudon C, Bayliss EA, van den Akker M. Multimorbidity's many challenges. Time to focus on the needs of this vulnerable and growing population. BMJ. 2007;334(7602):1016-1017.

45. Stange KC, Jaén CR, Flocke SA, Miller WL, Crabtree BF, Zyzanski SJ. The value of a family physician. J Fam Pract. 1998;46(5):363-368.

46. Starfield B. Threads and yarns: weaving the tapestry of comorbidity. Ann Fam Med. 2006;4(2):101-103.

47. Colton R, Frisof KB, King ER. Lessons for the health care industry form America's experience with public utilities. J Public Health Policy. 1998;18(4):389-400.

48. Cebul RD, Rebitzer JB, Taylor LJ, Votruba M. Organizational Fragmentation and Care Quality in the US Health Care System. NBER Working Paper. 2008;No. 14212. http://www.nber.org/papers/w14212. Accessed Jan 31, 2009.

49. Franks $P$, Clancy CM, Nutting PA. Gatekeeping revisited-protecting patients from overtreatment. N Engl J Med. 1992;327(6):424-429.

50. Geyman JP. Moral hazard and consumer-driven health care: a fundamentally flawed concept. Int J Health Serv. 2007;37(2):333-351.

51. Sox HC. Medical professionalism in the new millennium: a physician charter. Ann Intern Med. 2002;136(3):243-246.

52. Starr P. The Social Origins of Professional Sovereignty. The Social Transformation of American Medicine. New York, NY: Harper Collins Publishers; 1982:3-29.

53. Heath I, Sweeney K. Medical generalists: connecting the map and the territory. BMJ. 2005;331(7530):1462-1464.

54. BrainyQuote Web site. Disease quotes. http://www.brainy-quotes. com/quotes/disease. Accessed Jan 28, 2009.

55. Egnew TR. The meaning of healing: transcending suffering. Ann Fam Med. 2005;3(3):255-262.

56. Schoen C, Osborn R, Doty MM, Bishop M, Peugh J, Murukutla N. Toward higher-performance health systems: adults' health care experiences in seven countries, 2007. Health Aff (Millwood). 2007;26(6):w717-w734.

57. Pater JE. The Making of the National Health Service. London: King Edward's Hospital Fund for London; 1981.

58. Berwick DM. A transatlantic review of the NHS at 60. BMJ. 2008;337:a838.

59. Leatherman S, Berwick DM. The NHS through American eyes. BMJ. 2000;321(7276):1545-1546.

60. Stange KC. The best of times and worst of times. Br J Gen Pract. 2001;51(473):963-966. 